\title{
シンポジウム2 予防医療と臨床の連携
}

【座長のことば】

聖路加国際病院附属クリニック 予防医療センター 特別顧問 増苗勝紀

予防医療あるいは健診の現場と臨床の連携はもとより一体のものであり、この連携がスムーズ、シー ムレスでないと一体何のための健診と非難されることになります。健診は予防医療の第 1 歩であり、 1 次予防、2 次予防を推進するうえで臨床との密な関係を構築しなければなりません。健診側から要 精密検査、あるいは要治療と判断されてクリニック・病院を受診しても門前払いされ、戸惑う受信者 は珍しくはありません。その逆に受診勧奨が遅れて二次予防にならなかった例など健診に対する不信 感につながる場合もあります。

当学会加盟施設における検査の基準值や判定区分は各施設独自のものも多いため施設により精密検 査頻度や臨床受診率にばらつきあります。当学会あり方委員会ではこのばらつきを是正し、臨床側の 意を汲んだ適正な判定区分に取り組んできました。

臨床側からの提言を導入。内科学会を中心に現在 $17 の$ 学会・団体が加盟する脳心血管病協議会によっ て脳心血管病という概念が成立、当学会はこれを重要と捉え脳心血管病予防に関する包括的リスク管 理チャートを導入しました。これは血管を臟器としてとらえると死因第 2 位の心疾患と 4 位の脳血管 障害を合わせると悪性腫瘍と同等となり、したがって脳心血管病予防は健診側が意識して取り組む重 要な課題となりました。当学会では第45回大会から包括的リスク管理チャート健診版の作成に取り組 んできました。昨年度は脂質異常関し吹田スコアーの応用は適切な指導・受診勧奨の有力な手法であ ることが示されました。

こうした取り組みは臨床との連携の一部にすぎません。コロナの影響で医療機関受診をためらう国 民も多いようです、無駄の無い充実した健診を目指し、今シンポジウムでは臨床側の立場から健診側 への忌憚のない批判・意見を頂けるものと期待いたします。 


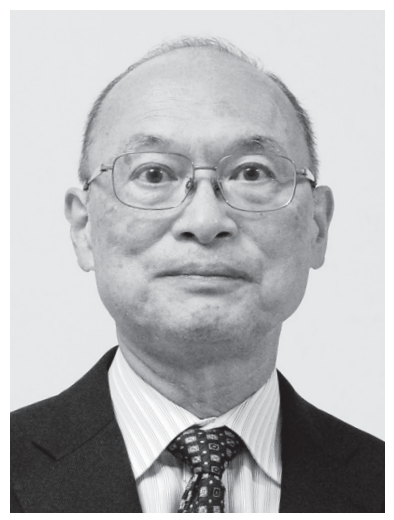

聖路加国際病院附属クリニック 予防医療センター 特別顧問

\section{曽苗勝紀}

\section{【学歴及び職歴】}

昭和 50 年 3 月 東京慈恵会医科大学卒業

昭和 54 年 3 月 大学院博士課程 学位（医学博士）取得

昭和 58 年 12 月 東京慈恵会医科大学第 2 外科教室助手

平成元年 8 月 東京慈恵会医科大学内視鏡科 講師

平成11年 5 月 東京慈恵会医科大学内視鏡科 助教授

平成14年 4 月 聖路加国際病院予防医療センター内視鏡科 医長

平成21年 4 月 聖路加国際病院附属クリニック予防医療センター長

令和 2 年 4 月 聖路加国際病院附属クリニック予防医療センター 特別顧問

\section{【資格・役職】}

学会認定専門医・指導医資格

日本総合健診医学会 理事 認定専門医・指導医

日本消化器内視鏡学会 評議員 認定専門医 - 指導医

日本外科学会 認定専門医

日本消化器外科学会 認定医

日本 PEG・在宅医療学会 理事 認定専門医・指導医

\section{【所属学会・研究会】}

日本総合健診医学会、日本人間ドック学会、日本消化器がん検診学会、日本消化器内視鏡学会、日 本外科学会、日本消化器外科学会、日本内視鏡外科学会、日本 PEG 在宅医療学会、日本レーザー医 学会

\section{【学会活動】}

平成25年 9 月 日本 PEG 在宅医療学会 第19回学術集会＼cjkstart会長

$$
\text { ステーションカンファランス東京 }
$$

平成28年 2 月 日本総合検診医学会 第44回学術大会 大会長

京王プラザホテル 